To keep abreast of advancing knowledge of drugs and their actions is no mean task. The author has succeeded in presenting a balanced picture of modern drug therapy without a burden of detail.

Older drugs, for example Mist Ferri et Ammon. Cit. and Crystal Violet, as an anthelmintic, are deleted. Newer ones, such as tranquillizing drugs and cortisone preparations, are added.

The re-written chapter on fluid balance gives a simple theoretical explanation of clinical infusions. It is regrettable that notes on the term milligramequivalent are omitted, but the author, no doubt, has good reason for this.

It remains the best book of its kind for nurses. M.A.L.

\section{THE CLINICAL MANAGEMENT OF VARICOSE VEINS}

By D. W. Barrow, M.D. Second edition. Pp. xiii $+\mathrm{I} 69$, with 70 illustrations. London: Cassell \& Co. Ltd. I957. 45s.

It has been a pleasure to read this short monograph on the clinical management of patients with varicose veins. Short chapters on anatomy, physiology and pathology are followed by a concise, practical account of the methods the author recommends for the investigation and treatment of these patients. The emphasis has been upon the practical side of the problem. This is not a complete monograph and does not pretend to be one, but it presents in a readable form the author's views upon how to treat patients with varicose veins and their commoner complications.

It is of interest that the approach to these patients appears to be nearly the same in Milwaukee, Wisconsin, as in Paddington, London.

\section{C.G.R.}

\section{PROGRESS IN HEMATOLOGY}

\section{Volume I}

Edited by L. M. Tocantins, M.D. Pp. ix + 336, illustrated. New York and London: Grune and Stratton Inc. 1956 . $\$ 9.75$.

A periodic survey of the progress of haematology is the chief intention of this publication, and the frequency of future volumes will depend on the advances in haematology, so it is stated in the introduction.

The 16 papers gathered here are almost without exception masterpieces of reviews of their subjects written by the masters themselves. Though advances have been made since their writing making the papers themselves partly out of date at the time of publication, the overall picture is well presented. Perhaps, unfortunately, few of the papers have summaries and the references are mostly very awkwardly arranged.

The only non-American team amongst the contributors are Drs. Ungley and Thompson of New- castle, who discuss very reasonably gastric intrinsic factor and Vitamin $\mathrm{B}_{12}$ inter-relationships. Various aspects of iron deficiency anaemia, of haemolytic disease, abnormal haemoglobins, systemic lupus erythematosus and polycythaemia are presented. The auto-immune thrombocytopenias, acute fibrinogen deficiencies and agammaglobulinaemia are well covered. A surgeon (A. F. di Palma of Philadelphia) provides guiding principles in the surgery of haemophilic patients-a very useful outline.

Burchenal and Ellison's essay on the chemotherapy of leukaemia is perhaps the best written and best arranged in an already fine collection. Valentine's survey of the biochemistry and enzymatic activities of leucocytes in health and disease is a very balanced critical review.

Although this book fairly represents the growth and the growing importance of haematology during the last 20 or so years, and although the book will certainly be useful for every haematologist, this reviewer cannot help feeling that the place for such papers is in journals of haematology, which are themselves perhaps already too numerous. $\mathrm{He}$ is, however, very glad to see them collected in one volume.

$$
\text { E. } \mathbf{N} \text {. }
$$

\section{FUNDAMENTALS OF CLINICAL FLUOROSCOPY}

By Charles B. Storch, M.D. Second edition Pp. xiii +305 , with 318 illustrations. New Yond and London: Grune and Stratton Inc. 1956. $\$ 8.7$ ?

Dr. Storch's book is the second edition of a work previously published in $195^{\circ}$. It covers in great detail the practical aspects of radiological screening and as such is addressed primarily to $\frac{\circ}{D}$ students of radiology.

The mode of presentation is perhaps more $\overrightarrow{\vec{O}}$ adapted to American than to British students, many $\frac{3}{3}$ of whom will find the 'Question and Answer' type of legend beneath diagrams rather irritating. However, the views expressed are generally comprehensive and sound, and will prove'most helpful to the trainee radiologist.

D.S.

\section{CYTOLOGIC TECHNICS \\ For Office and Clinic}

By H. E. Nieburgs, M.D. Pp. viii +232, with 171 을. illustrations. New York and London: Grune No and Stratton Inc. I 956 . $\$ 7.75$.

Although some may disagree with the statement 0 in the preface that ' cancer detection and diagnosis $\omega$ has been greatly enhanced by the study of exfoliative cytology,' there is no doubt that this com-o paratively short book is a very useful one. It avoids mostly purely cytological details and presents $\stackrel{\oplus}{?}$ the techniques used in the surgery or clinic or even 0 
the theatre. Mouth, larynx, sinuses, lungs, oesophagus, stomach, duodenum, colon and rectum, vulva, cervix, endometrium, tubes, ovaries, breast, pleural, peritoneal and pericardial fluids, urine, prostate and skin are discussed as possibly containing material for cancer diagnosis. Lymph gland, bone marrow and brain biopsies only receive a short chapter. The organization of a lavishly equipped cytological laboratory is well shown, and some laboratory precedures are given in detail. It is worth remembering that $\mathrm{Dr}$. Nieburgs regards 9 to 12 months as the minimal training period for a cytological technician by an experienced cyto-pathologist. The pathologist's training should be at least one year.

$$
\text { E.N. }
$$

\section{MEDICAL RESEARCH}

\section{A Mid-Centenary Review}

Published for the American Foundation. Vol. I, pp. 765; Vol. II, pp. 740. London: J. \& A. Churchill Ltd. I05s. per set.

The American Foundation was established to enquire objectively into subjects of national and international importance. These have included law in international disputes, relations between the U.S.A. and the U.S.S.R.; and community medical care.

In these two volumes, aided by a large panel of consultants of world note, the Foundation turns its attention to the purpose, the practice and the finance of medical research in the U.S.A.

The first volume presents medical research against the background of the fundamental sciences of biology, chemistry, physics and mathematics, outlining their interrelationships. It examines current attitudes to the organization of research, arguing the case for and against large-scale planning, and assessing the role of the Government in research. It is of interest that the section dealing with the scientists' relation to society in connection with nuclear weapons draws freely, heavily and almost solely on the public statements of British scientists and philosophers. The rest of the first volume considers agencies sponsoring research, and the 'clearing of results.' World scientific literature, UNESCO estimates, carries now $1,850,000$ articles a year.
Volume II surveys in detail the present state of knowledge and directions in research concerning nine unsolved clinical problems. These are cancer, infertility, arteriosclerosis, hypertension, the rheumatic syndromes, tuberculosis, the nature of viruses and virus diseases, alcoholism, and the biology of schizophrenia. While material of this sort makes uncomfortable reading, each of the sections is of the greatest value in covering the whole field, pointing out where it is potentially fertile and unexplored, and where it is worked to death. References to original work abound, and are not, of course, confined to American workers.

This is an Albert Memorial of a work, square, sound, solid and detailed, of set purpose and skilled execution; but rather unbeautiful.

H.K.

\section{THE ROYAL LONDON HOMOEOPATHIC HOSPITAL}

\author{
Great Ormond Street, London, W.C.I
}

\section{APPOINTMENT OF CLINICAL ASSISTANTS}

Applications are invited from registered medical practitioners for two appointments of Clinical Assistants each of two sessions at the Royal London Homoeopathic Hospital and each with a bursary of $£ 250$ offered by The Homoeopathic Research and Educational Trust to provide for attendance at the hospital's course of instruction in homoeopathy. Commencing on the 10th October, 1957 with a view to qualifying for the diploma of the Faculty of Homoeopathy. Applications to the Secretary, The Royal London Homoeopathic Hospital, Gt. Ormond Street, W.C.1.

\section{NOTICE OF SPECIAL INTEREST TO SUBSCRIBERS:}

$$
\begin{aligned}
& \text { 'WHY NOT HAVE YOUR COPIES OF THIS } \\
& \text { JOURNAL BOUND INTO YEARLY VOLUMES?' }
\end{aligned}
$$

You can have your twelve monthly issues fully bound in dark green pin head cloth, lettered in gilt on spine with name of Journal, Volume Number and year, complete with index at front, for 21s. Od. post free. A limited number of out of print journals are available to bind into volumes and make your library complete. Price on application giving details of issues required to complete back volumes.

THE FELLOWSHIP OF POSTGRADUATE MEDICINE 60 PORTLAND PLACE, LONDON, W.I
WHY NOT HAVE YOUR JOURNALS BOUND? 